V. Vanko, DSc, Prof., O. Prikhodko

Lviv Polytechnic National University, 12 Bandery Str., Lviv, Ukraine, 79013; e-mail: vvm510@ukr.net

\title{
IMPROVEMENT OF THE QUALITY MANAGEMENT SYSTEM OF MANUFACTURING OF MACHINE-BUILDING PRODUCTION
}

В.М. Ванько, О.М. Приходько. Вдосконалення системи управління якістю виробництва машинобудівної продукції. На підставі аналізу вимог чинних нормативних документів запропоновано підхід для покращання ефективності системи управління якістю машинобудівного виробництва завдяки застосуванню теорії матричного числення та аналізу ризиків через різні види та наслідки потенційних відмов у споживача (FMEA). Систематизовано та досліджено перелік технологічних процесів виробництва гільзи циліндра двигуна внутрішнього згорання на основі складених двох причинно-наслідкових діаграм Ісікави та часткових векторів якості даних процесів. Встановлено напрями оптимального управління процесами виготовлення з метою забезпечення ефективного управління якістю даної гільзи.

Ключові слова: система управління якістю, гільза циліндра, одиничний показний якості, матриця якості, еталонний вектор, діаграма Ісікави, FMEA

V. Vanko, O. Prikhodko. Improvement of the quality management system of manufacturing of machine-building production. Based on the analysis of the current normative documents' requirements an approach is proposed to improve the efficiency of the quality management system of the machine-building production through the application of the theory of matrix calculation and risk analysis through the various types and effects of potential customer failures (FMEA). The list of technological processes of production of the internal combustion engine's cylinder sleeve is systematized and investigated on the basis of the combined two cause and effect Ishikawa diagrams and partial quality vectors of these processes. The directions of optimal control of production processes are established in order to ensure the efficient management of the quality of this sleeve.

Keywords: Quality Management System, cylinder sleeve, unitary quality score, quality matrix, reference vector, Ishikawa diagram, FMEA

Introduction. Today, Ukrainian enterprises are trying to get their products on international markets. In this case, a special problem is the need to guarantee the appropriate quality of products. According to the requirements of the current normative documents [1,2], solving this problem should be approached comprehensively. This is achieved through a Quality Management System (QMS) for the enterprise.

Recent researches and publications analysis. As it's well known, any QMS is a generalized structure which consists of four global systems:

- production;

- monitoring, measuring, analyzing and studying for improvement;

- management responsibility, which includes a strategy and policy to achieve sustainable success;

- resource management [1 - 3].

This structure of the QMS has undergone a thorough inspection in the USA, Europe, Japan, South Korea, China, and so on in recent years. The products of these countries are fairly in demand because they are high quality, inexpensive and reliable.

\section{DOI: 10.15276/opu.1.54.2018.15}

(c) 2018 The Authors. This is an open access article under the CC BY license (http://creativecommons.org/licenses/by/4.0/). 
Such tendencies contributed to the development of QMS, methods and tools for monitoring the quality of products and services [4-6]. At the moment, scientists and leading experts prefer the methodology of the process approach, based on the Deming cycle "Plan-Do-Check-Act".

For the Ukrainian machine-building enterprises, the most important thing today is the establishment of an optimal production management system that will ensure the production of competitive products. Therefore, among the above management systems, in the future we will consider the actual QMS of production.

Guaranteeing the implementation of the stages of the products life cycle, related to the production of complex technical products, needs a highly effective QMS, which will fully take into account the specifics of production and the work with advanced and accurate equipment. At the moment, there are different variants of the similar QMS, but, based on their presentation, there is a lack of specifics in terms of implementation and obvious application, especially in the cases of the manufacture of relatively simple blocks, nodes and elements.

Purpose of research. Formation of an improved management system of the manufacture of an internal combustion engine's cylinder sleeve using a matrix method means of control, analysis and products quality management and recommendations of current normative documents DSTU ISO 9000.

Presentation of basic material. One of the promising directions of creating effective QMS of production is the use of the theory of matrix calculus for a relatively simple analytical representation of technological and other processes [7]. The main task of such QMS is the consistent implementation of all subsequent the life cycle stages of machine-building products:

- designing a product in the form of $1,2, \ldots$, and partial vectors or quality matrices $\left|\left(Q_{0}\right)_{1-\text { des }}\right| . . .\left|\left(Q_{0}\right)_{a-\text { des }}\right|$;

- preparation of production as a plurality $\left|\left(Q_{0}\right)_{1-\mathrm{pp}}\right| \ldots\left|\left(Q_{0}\right)_{b-\mathrm{pp}}\right|$;

- complex of technological processes of production in the form of $\left|\left(Q_{0}\right)_{1-\mathrm{tp}}\right| \ldots\left|\left(Q_{0}\right)_{c-\mathrm{tp}}\right|$;

- output control of the finished product as $\left|\left(Q_{0}\right)_{s-\mathrm{oc}}\right| \ldots\left|\left(Q_{0}\right)_{S \text {-oc }}\right|[8]$.

At the same time, each of these stages represents a set of various processes that are described in the sets of given partial vectors or quality matrices by means of specially ordered groups of unitary quality score (UQS). According to [1,2] for each of the following stages of the product life cycle, a certain set of processes necessary for its implementation is typical. And current regulatory documents recommend each process should be considered as a sequence of interrelated elements:

- input sources (previous processes from suppliers, customers, other interested parties);

- inputs complex (matter, energy and information in the form of materials, resources and requirements);

- a set of actions; solutions);

- outputs complex (matter, energy and information in the form of products, services and

- outputs recipients (follow-up processes for customers and other parties).

Control points are considered as possible means of control, in which the monitoring and measurement of the process efficiency are monitored. Such a reflection of a typical technological process in the practice of machine-building enterprises is not always adequate - sometimes they are significantly influenced by other accompanying processes or external factors.

Consider as an example a complex of processes related to the production of cylinder sleeve AL 0908.3012.2017. This is a long cylindrical part, relatively simple form, which is one of the most responsible units of the internal combustion engine SMD-14, which is installed on large-scale agricultural machinery: tractors and combines. The reliability of the operation of this technique essentially depends on the sleeve of the cylinder, in which the piston moves, ensuring the movement of this technique.

From the whole set of processes and procedures for the manufacture of cylinder sleeves we distinguish the main: casting and machining. 
According to the theory of qualimetry, the assessment of quality should be based on the analysis of information about the object under study. That is, if the first step is the collection of data, then in the future it is necessary to look for reasons of deterioration of quality and to form the necessary corrective actions. As it's well known [4-6,8], the cause and effect Ishikawa diagrams serve as such tools. In this case, the dispersion of the information received to groups of UQSs, relating to:

- technology (partial matrix or $\mathbf{T}$-quality vector);

- machinery and equipment (matrix or quality vector $\mathbf{E}$ );

- staff (matrix or quality vector $\mathbf{S}$ );

- raw materials (matrix or quality vector $\mathbf{M}$ ).

This quality assessment structure is generalized and may vary, depending on the features of the product and the processes of its production. The fact is that the number of the above groups of UQSs (reasons for a possible deterioration in quality) may be increased to six if necessary [4-6].

Consequently, for a set of processes of molding casings, the cause and effect Ishikawa diagram will have the form shown in Fig. 1.

It should be noted that in this case, the technological processes include: the input control of IC, the preparation of the charge (PC), the manufacturing and research of the sample (MRS), the manufacturing of workpieces (MW). To find out the problem that may arise in the investigated process, it is necessary to highlight the main causes - the lines aimed at the thick horizontal line. Analytically, they are presented in the form of the above-mentioned quality vectors $\mathbf{T}, \mathbf{E}, \mathbf{S}$ and $\mathbf{M}$.

Consider UQSs that relate to each of these processes. Thinner arrows in Fig. 1, which are directed to these four lines, are factors (UQSs) that contribute to the emergence of each of them.

Regarding the IC should be separated: the supporting documents on primary materials -2.2 (UQS $n_{\mathrm{p}-2.2}$ ), forced replacement of the primary material - 4.3 (UQS $n_{\mathrm{p}-4.3}$ ), pre-sorting material -4.2 (UQS $n_{\mathrm{p}-4.2}$ ), the inaccurate selection of charge material - 4.1 (UQS $n_{\mathrm{p}-4.1}$ ).

Performing the PC should be investigated: the sorting of the charge components - 4.2 (UQS $n_{\mathrm{p}-4.2}$ ); the replacement of material in a charge -4.3 (UQS $n_{\mathrm{p}-4.3}$ ); the availability of finished packaging-3.1 (UQS $n_{\mathrm{p}-3.1}$ ); the requirements to the weight of the charge - 1.3 (UQS $n_{\mathrm{p}-1.3}$ ), the appearance of which additionally should take into account the mismatch of sleeves by mechanical properties -2.5 (UQS $n_{\mathrm{p}-2.5}$ ); the untimely loading and packaging - 3.3 (UQS $n_{\mathrm{p}-3.3}$ ), which is accompanied by a delay in the preparation of the metal-1.2 (UQS $n_{\mathrm{p}-1.2}$ ).

During the MRS, should be analyzed: the readiness of the furnace and the bucket -2.2 (UQS $n_{\mathrm{p}-2.2}$ ), which can cause the failures and delays in the process - 1.2 (UQS $n_{\mathrm{p}-1.2}$ ); the absence of haz-

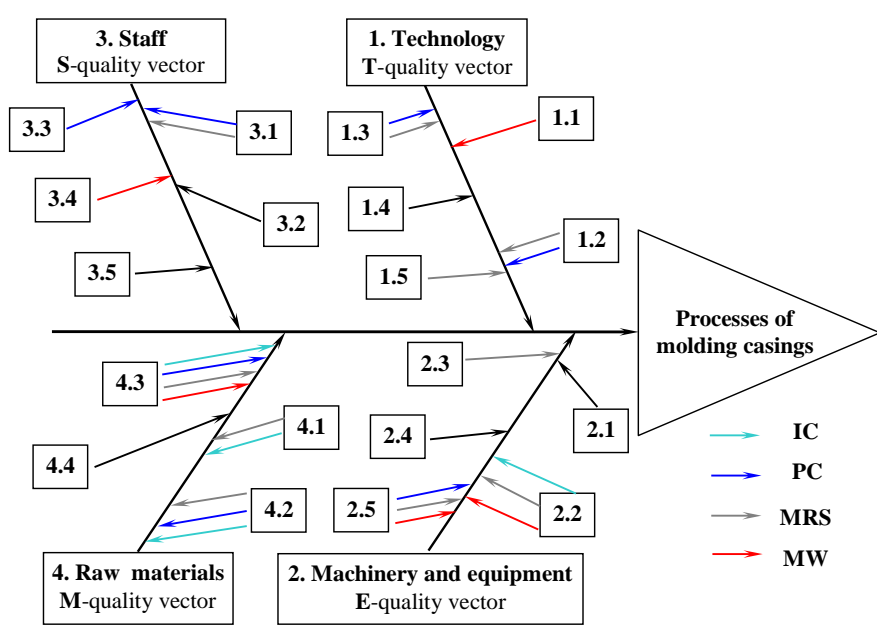

Fig. 1. Cause and effect Ishikawa diagram for casings molding processes ardous substances in the sample - 4.2 (UQS $n_{\mathrm{p}-4.2}$ ); the conformity of constituents - 4.1 (UQS $n_{\mathrm{p}-4.1}$ ); the sample casting - 1.3 (UQS $n_{\mathrm{p}-1.3}$ ); the timely sending samples - 3.1 (UQS $n_{\mathrm{p}-3.1}$ ); checking chemical composition of the sample -4.3 (UQS $n_{\mathrm{p}-4.3}$ ); the spectral setting - 2.3 (UQS $n_{\mathrm{p}-2.3}$ ); the destruction and checking on the hardness of the sample - 1.3 (UQS $\left.n_{\mathrm{p}-1.3)}\right)$; the microstructure test of the sample -1.5 (UQS $n_{\mathrm{p}-1.5}$ ); the clearing of slag -2.5 (UQS $n_{\mathrm{p}-2.5}$ ). In this case, in order to ensure the efficiency and reliability of the engine, the chemical composition of the sleeve material should be appropriate to the Table. 
The chemical composition of the sleeve material, \%

\begin{tabular}{|c|c|c|c|c|c|c|c|c|}
\hline \multirow{2}{*}{ Cast iron } & \multirow{2}{*}{$\mathrm{C}$} & \multirow{2}{*}{ Mo } & \multirow{2}{*}{$\mathrm{Mn}$} & \multirow{2}{*}{$\mathrm{Cr}$} & $\mathrm{S}$ & $P$ & \multirow{2}{*}{$\mathrm{Cu}$} & \multirow{2}{*}{$\mathrm{Ni}$} \\
\hline & & & & & \multicolumn{2}{|c|}{ Not more } & & \\
\hline $\begin{array}{c}\text { GJL-240 } \\
\text { (EN1561) }\end{array}$ & $3.1 \ldots 3.5$ & $2.0 \ldots 2.4$ & $0.7 \ldots 1.0$ & $0.3 \ldots 0.5$ & 0.15 & $0.45 \ldots 0.7$ & 0.3 & 0.3 \\
\hline
\end{tabular}

During MW should be controlled: the equipment preparation (dispenser, roundabout-cocker installation and caliber) -2.2 (UQS $n_{\mathrm{p}-2.2}$ ); the control of the density of the heat-insulating paint -3.4 (UQS $n_{\mathrm{p}-3.4}$ ); the installation of equipment regimes and cooling schemes - 2.5 (UQS $n_{\mathrm{p}-2.5}$ ); the time of delivery of a bucket of liquid metal to the dispenser and the filling of the metal-1.1 (UQS $n_{\mathrm{p}-1.1}$ ); the sample control - 4.3 (UQS $n_{\mathrm{p}-4.3}$ ).

Note that in Fig. 1 not all factors (UQS) are used. This is due to the fact that they are sometimes extremely important. It is about: the parameters of the environment in the production facility 1.4 , the operating conditions 2.1 , the inattention of the various, including non-standard equipment -2.4 , insufficient qualifications of staff -3.2 , the workplace of the employee -3.5 and the quality of the party from the supplier in all aspects, including his reputation -4.4 .

Taking into account the mechanics, the cylinder sleeve is a body of rotation and has the following structural elements: external cylindrical surfaces, internal cylindrical surface, three ends, external and internal chamfers, conical surface and two halves.

For a set of processes of mechanical processing of sleeves, the following cause

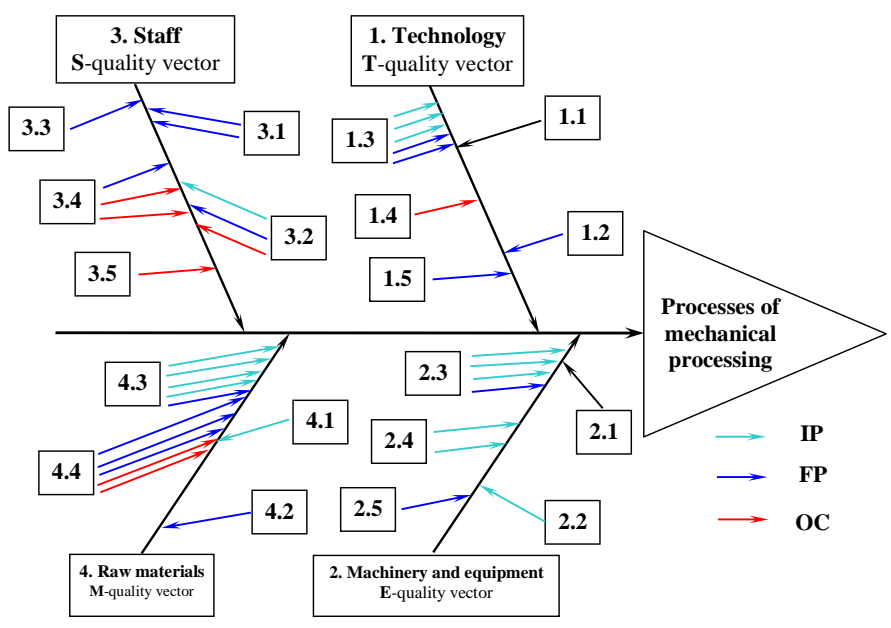

Fig. 2. Causal and effect Ishikawa diagram for the processes of mechanical processing of sleeves and effect Ishikawa diagram is depicted in

Fig. 2, which describes the technological processes: initial processing (IP), final processing (FP), and output control (OC).

As well as for the previous group of processes, consider the UQS, describing each of the above processes.

At initial processing we'lP have: the breakage of a cutter - 2.3 (UQS $n_{\mathrm{p}-2.3}$ ); the deviation in the size of the cutting length of the workpiece - 1.3 (UQS $n_{\mathrm{p}-1.3}$ ); the bleaching of cast iron workpiece 4.3 (UQS $n_{\mathrm{p}-4.3}$ ); the deviation of wall size - 1.3 (UQS $\left.n_{\mathrm{p}-1.3}\right)$; the deflection of the diameter of the hole 2.3 (UQS $n_{\mathrm{p}-2.3}$ ); non-compliance with roughness requirements - 4.3 (UQS $n_{\mathrm{p}-4.3}$ ); the increasing wear and tear of the cutter - 2.3 (UQS $n_{\mathrm{p}-2.3}$ ); the wrong geometry of the surface-2.4 (UQS $n_{\mathrm{p}-2.4}$ ); the wrong length of workpiece - 1.3 (UQS $n_{\mathrm{p}-1.3}$ ), which is accompanied by UQS 4.3; the wrong shirt diameter 4.1 (UQS $n_{\mathrm{p}-4.1}$ ), which causes UQS 4.5 ; the disturbance of centering (the beating the mandrel) -2.2 (UQS $n_{\mathrm{p}-2.2}$ ), which causes appearance of UQS the inattention to the staff 3.2 (UQS $n_{\mathrm{p}-3.2}$ ) and UQS 2.4.

Regarding the FP should be noted: the wrong height of the clamp - 1.3 (UQS $n_{\mathrm{p}-1.3}$ ), which is accompanied by UQS 2.3; the unsaturated shirt sizes - 4.3 (UQS $n_{\mathrm{p}-4.3}$ ), which results in the quality of the party from the supplier in all respects, including its reputation -4.4 (UQS $n_{\mathrm{p}-4.4}$ ); the increasing of beating in the engine -4.4 (UQS $n_{\mathrm{p}-4.4}$ ); the radius of the duct under the hill is not maintained -1.3 
(UQS $n_{\mathrm{p}-1.3}$ ), which causes UQS 4.4; the unsatisfied roughness - 3.1 (UQS $n_{\mathrm{p}-3.1}$ ), which causes UQS 3.2 ; the instability of microgeometric characteristics - 3.1 (UQS $n_{\mathrm{p}-3.1}$ ), which causes appearance of UQS the untimely loading and packaging - 3.3 (UQS $n_{\mathrm{p}-3.3}$ ); the deviation from colloquialness and straightforwardness - 1.5 (UQS $n_{\mathrm{p}-1.5}$ ), which causes insufficient control-3.4 (UQS $n_{\mathrm{p}-3.4}$ ).

During the OC should be analyzed: the formation of the sleeve - 1.4 (UQS $n_{\mathrm{p}-1.4}$ ), which causes UQS 4.4 the critical parameters defect was not detected - 3.4 (UQS $n_{\mathrm{p}-3.4}$ ), which causes UQS 4.4; the critical parameters defect was not detected - 3.2 (UQS $n_{\mathrm{p}-3.2}$ ), which causes UQS insufficient control 3.4; the violation of storage and transportation conditions - 3.5 (UQS $n_{\mathrm{p}-3.5}$ ).

Proceeding from the requirements of the current normative documents, quality control of any process can be carried out by traditional means of quality monitoring, and additional methods of risk assessment can be applied.

The proposed version of the production quality assessment is expedient to use with the FMEA method - failure mode and effects analysis of potential customer failures due to possible defects in products and processes of its production $[4-6,8]$.

The main tasks of FMEA are the establishment of:

- possible failures (defects) of products or process, their causes and effects;

- degree of significance $S$ of effects for consumers, the probability $O$ of occurrence of causes (defects) and their detection $D$ before the consumer receives;

- a generalized assessment for each $p$-th of UQS of the object of analysis by identifying a priority number of risk

$$
n_{p}=S_{p} O_{p} D_{p}
$$

and comparing it with the maximum permissible value of $p\left(n_{p}\right)_{\mathrm{h}}$; condition

- measures to improve the quality of the object of analysis, which is achieved by observing the

$$
n_{p}<\left(n_{p}\right)_{\mathrm{h}} .
$$

This condition must be met for all UQS s that characterize an object in view of its high quality [9].

Thus, using expression (1), as a result of the study of this object, the partial vectors of quality, as suggested above, are initially formed:

$$
\begin{aligned}
& \mathbf{Q}_{\mathrm{IC}}=\left|\begin{array}{llll}
n_{p-2.2} & n_{p-4.3} & n_{p-4.2} & n_{p-4.1}
\end{array}\right|=\left|\begin{array}{llll}
48 & 72 & 180 & 72
\end{array}\right|,
\end{aligned}
$$

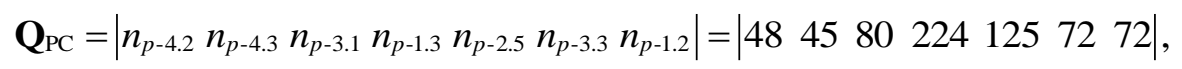

$$
\begin{aligned}
& \mathbf{Q}_{\mathrm{MRS}}=\left|n_{p-2.2} n_{p-1.2} n_{p-4.2} n_{p-4.1} n_{p-1.3} n_{p-3.1} n_{p-4.3} n_{p-2.3} n_{p-1.3} n_{p-1.5} n_{p-2.5}\right|=
\end{aligned}
$$

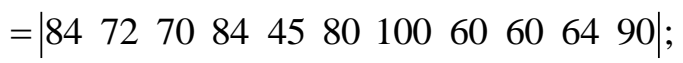

$$
\begin{aligned}
& \mathbf{Q}_{\mathrm{MW}}=\left|n_{p-2.2} n_{p-3.4} n_{p-2.5} n_{p-1.1} n_{p-4.3}\right|=\left|\begin{array}{lllll}
72 & 63 & 84 & 45 & 80
\end{array}\right| \text { - for molding sleeves and } \\
& \mathbf{Q}_{\mathrm{IP}}=\left|n_{p-2.3} n_{p-1.3} n_{p-4.3} n_{p-1.3} n_{p-2.3} n_{p-4.3} n_{p-2.3} n_{p-2.4} n_{p-1.3} n_{p-4.3} n_{p-4.1} n_{p-4.3} n_{p-2.2} n_{p-3.2} n_{p-2.4}\right|=
\end{aligned}
$$

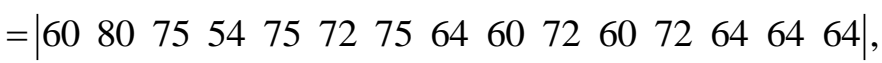

$$
\begin{aligned}
& \mathbf{Q}_{\mathrm{FP}}=\left|n_{p-1.3} n_{p-2.3} n_{p-4.3} n_{p-4.4} n_{p-4.4} n_{p-1.3} n_{p-4.4} n_{p-3.1} n_{p-3.2} n_{p-3.1} n_{p-3.3} n_{p-1.5} n_{p-3.4}\right|=
\end{aligned}
$$

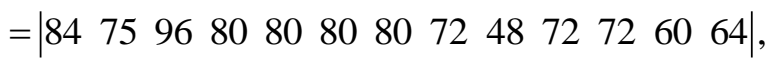

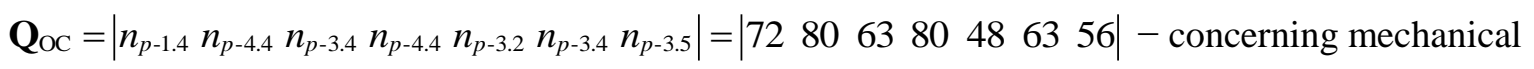

$$
\begin{aligned}
& \text { processing of sleeves. }
\end{aligned}
$$

In the future, based on the expression (2) and the normative documents' requirements, form partial reference quality vectors for these processes. Their comparison with the above-mentioned quality 
vectors allows, firstly, to identify probable risks for the processes and procedures under consideration, and, secondly, to find out in which places the UQSs come up with critical values that can lead to deterioration of the product quality. On the example of the MRS process, the condition for guaranteeing the permissible quality level of the cylinder sleeve will be compliance with the condition

$$
\mathbf{Q}_{\mathrm{MRS}}<\left(\mathbf{Q}_{\mathrm{MRS}}\right)_{\mathrm{st}} \text {. }
$$

Results. Based on the data obtained regarding the specified sleeve for the internal combustion engine, it can be argued that the directions of optimal quality control of the technology for its production should be considered:

- the observance of scrupulous input control on primary materials and semi-finished products;

- the need for further development of processes of preparation of the charge and the manufacture of a sample to minimize deficiencies during the production of a batch of cartridges;

- the need for improvement of the processes of final processing of the billet preparations, where the most precise mechanical operations are concentrated.

It should be noted that based on the results of the selected object research (Fig. 1 and Fig. 2), it can be argued about some inadequacy of the above and cited in $[1,2]$ schematic representation of a typical unit process, such as production, and the interaction of its elements. In this case, there are no possible effects of other accompanying processes, as well as external factors. That is, there is a need for a better formation of regulatory requirements to typical production processes.

According to the above Ishikawa diagrams, there are individual UQSs whose effects on the final quality of the product or technological processes are observed in different processes simultaneously or indirectly.

It is obvious that in order to formulate more specific requirements regarding the presentation of partial reference quality vectors for the specified sleeve production processes, there is a need for a more detailed analysis of the normative documents on the FMEA and a longer collection of statistical information for this product.

Conclusions. Due to the proposed quality management system, such areas of the machinebuilding enterprise are identified that require immediate measures to ensure effective management of the quality of its operation. This allows formulating of a successful competitive policy for the production of goods attractive to consumers.

\section{Література}

1. Бичківський Р.В., Столярчук П.Г., Гамула П.Р. Метрологія, стандартизація, управління якістю і сертифікація: підручник. Львів : НУ Львівська політехніка, 2002. 560 с.

2. Бичківський Р.В., Столярчук П.Г., Сопільник Л.І., Калинський О.О. Управління якістю. Стандартизація: навч. посіб. Київ : Школа, 2005. 432 с.

3. Ванько В.М., Столярчук П.Г. Шляхи розвитку структури системи управління якістю продукції та послуг. Міжвід наук.-техн. збірник. Вимірювальна техніка та метрологія. 2010. №71. С. 164-170.

4. Эванс Д.Р. Управление качеством/ Пер. с англ. под ред. Э.М. Короткова. Москва : ЮНИТИ ДАНА, 2007. $671 \mathrm{c}$.

5. Кане М. М., Иванов Б. В., Корешков В. Н., Схиртладзе А. Г. Системы, методы и инструменты менеджмента качества: учеб. пособ. СПб. : Питер, 2008. 560 с.

6. Харрингтон Дж. Управление качеством в американских корпорациях. Москва : Экономика, 1990. 272 с.

7. Ванько В.М., Столярчук П.Г. Метод оцінки якості продукції та послуг за допомогою теорії матриць. Вимірювальна техніка та метрологія. 2007. № 67. С. 108-114.

8. Ванько В.М., Приходько О.М. Підхід для вдосконалення системи управління якістю машинобудівного підприємства. Technical Using of Measurement - 2018: тези доп. IV всеукр. наук.-техн. конф. мол. вчених у царині метрології (смт Славське, 13 - 18 лютого 2018). 2018. С. 73-75.

9. IEC 60812:2006. Analysis techniques for system reliability - Procedure for failure mode and effects analysis (FMEA). 


\section{References}

1. Bychkivskie R.V., Stoliarchuk P.G., \& Gamula P.R. (2002). Metrology, Standardization, Quality Management and Certification. Lviv: NU Lvivska politehnika.

2. Bychkivskie R.V., Stoliarchuk P.G., Sopilnyk L.I., \& Kalynskie A.A. (2005). Quality management. Standardization. Kyiv: Shkola.

3. Vanko V.M., \& Stoliarchuk P.G. (2010). Ways of developing the structure of the quality management system for products and services. Measurement Technology and Metrology, 71, 164-170.

4. Evans D.R. (2007). Total quality. Management, organization and strategy. Moscow: UNITY DANA.

5. Kane M.M., Ivanov B.V., Koreshkov V.N., \& Shirtladze A.G. (2008). Systems, methods and tools of quality management. Allowance. St. Petersburg.

6. Harrington H.J. (1987). The Improvement Process how America's leading Companies improve quality. Wisconsin, USA.

7. Vanko V.M., \& Stoliarchuk, P.G. (2007). Method for assessing the quality of products and services using the matrix theory. Measurement Technology and Metrology, 67, 108-114.

8. Vanko V.M., \& Prikhodko, O.M. (2018). Approach for improvement of the quality management system of the machine-building enterprise. Technical Using of Measurement.(pp. 73-75). Slavske, Ukraine.

9. IEC 60812:2006. Analysis techniques for system reliability - Procedure for failure mode and effects analysis (FMEA).

Ванько Володимир Михайлович; Vanko Volodymyr, ORCID: https://orcid.org/0000-0001-6317-5906 Приходько Олександр Миколайович; Prikhodko Oleksandr, ORCID: https://orcid.org/0000-0001-8523-185X 